\title{
Impact of Financial Sector Reforms on Farmers Access to Agricultural Credit in Nigeria, 1981 - 2016
}

\author{
Eyo Emmanuel O*, Agenson M. Eleojo \\ Department of Agricultural Economics, University of Calabar, Calabar, Nigeria
}

DOI: $10.36348 /$ sjbms.2019.v04i09.004

| Received: 11.08.2019 | Accepted: 22.08.2019 | Published: 20.09.2019

*Corresponding author: Emmanuel O. Eyo

\section{Abstract}

The study examined the impact of financial sector reforms on farmer's access to agricultural loan in Nigeria. The specific objectives were to; compare the volume of loan accessed by the different agricultural subsectors in the different reform era, estimate the determinants of farmers access to agricultural loan, and determine the effect of the different financial sector reform overtime on farmers' access to loan. Data for the study were obtained from CBN Statistical bulletin, CBN annual report, federal budget allocation report, annual reports and used for the study. Data obtained were analyzed using both descriptive and inferential statistics. The results showed that there was a significant difference in volume of loan accessed by the agricultural subsector. Results of the determinants of farmers' access to agricultural loan revealed that, savings mobilized by financial institution, government budget allocation to agriculture and credits to private sector were the significant determinants of farmer's access to agricultural loan. The study also revealed that financial sector regime era had a significant effect on farmers' access to loan.

Keywords: Financial Reforms, Agricultural Lcredit, Farmers, Nigeria.

Copyright @ 2019: This is an open-access article distributed under the terms of the Creative Commons Attribution license which permits unrestricted use, distribution, and reproduction in any medium for non-commercial use (NonCommercial, or CC-BY-NC) provided the original author and source are credited.

\section{INTRODUCTION}

Financial sector reforms is a regular feature of many financial systems and these reforms have evolved in response to challenges posed by developments in the system such as systemic crisis, globalization, technological innovation and financial crisis. Financial sector reforms constitute that aspect of economic reforms which focuses mainly on restructuring the financial institutions (regulators and operators) via institutional and policy reforms [1]. In the 1990's the issue of financial sector reforms has taken the center stage in the world's economy. Both developed and developing countries have tried to bring about reforms in their financial sectors in order to impact on the growth of either the entire economy or a sub-sector of the economy such as agriculture [2]. Financial sector reforms have been initiated with diverse objectives. A reform is "to change a system, law, organization etc. so that it operates in a fairer or more effective way" [3]. Globally, financial reforms in emergent economies have not only become more popular but have also become synonymous with, among others, the lessening of rules on interest rate and lending operations of banks, eradication of barriers to contest, as well as the reinforcement of the financial organizations and infrastructure [4]. According to [5], financial sector reforms are important to enable the private sector, instead of the state, decide on bank lending operations as well as to improve on bank regulation. Even though different reasons may underlie financial sector reforms, recent reforms have veered towards ensuring more financial strength and economic development [6]. Abiad and Mody [6] identified three major causes of reforms and referred to these as shocks, learning, and ideology and structure. According to Abiad and Mody, these shocks which include decisions of new governments, various types of crises and persuasion of foreign bodies such as the IMF have been the major causes of reforms in the past few decades.

In Nigeria, the importance of an economic reform became evident as a result of the background of economic problems, including stagnant growth, rising inflation, unemployment, food shortages and mounting 
external debt, which confronted the country since the early 1980's. The sharp reduction in crude oil prices resulted in deterioration in government's finances and foreign exchange earnings. As the country plunged into economic recession, the initial policy response was the adoption of stringent austerity measures in 1982 [7]. Financial sector reforms have been adopted by Nigerian government as a part of their economic reform program. Through this reform programs, the government intended to liberalize the financial sector and to ease the entry into banking sector [8].The reforms have evolved in response to the challenges posed by developments in the system such as systemic crisis, globalization, technological innovation and financial crisis [9]. In order to achieve efficient allocation of resources, the financial sector has to be well developed [10]. The financial sector in an economy promotes specialization, since it makes it easier to obtain the required funds for investments in productive projects, allowing borrowers to concentrate on their own areas of expertise. Responding to these identified challenges, the Central Bank of Nigeria unveiled a ten-year reform blue print anchored on four cardinal reform programs for the stabilization of the banking and financial sector in general. The transformation of the financial sector was based on four cardinal programs which include: enhancing the quality of banks, establishing financial stability, and ensuring that the financial sector contributes substantially to the real sector of the economy [11]. The reforms, as noted by Udedeh [12] are Free Banking Era (1892-1957), Regulated Era (1952-1991), Liberalized Regulation Era with specialized roles (1991-2000), Liberalized Regulation Era with Universal Roles (2000-2005), Regimented Regulation/Consolidation (2005-2009) and Regimented/Ownership solution (2009 to date).

Financial sector reform had been adopted by the Nigerian Government as a part of their economic reform program. Through this reform program the government intended to liberalize the financial sector and to ease the entry into the banking sector. Financial sector reform in Nigeria had been started with the deregulation of the rates of interest [13]. The financial conditions of Nigeria had been fragile and unstable for more than two decades after independence. Lot of complex restrictions was there on the entry into the banking sector and exchange rates were high. The fiscal deficits were increasing and so was the rate of inflation. So, the government of Nigeria implemented financial reforms in the country. There had been various segments of the reform in Nigeria. The first occurred during 1986 to 1993 , when the banking industry was deregulated in order to allow for substantial private sector participation. Hitherto, the landscape was dominated by banks which emerged from the indigenization programme of the 1970s, which left the Federal and state governments with majority stakes. However, the major financial reforms within this period have therefore been classified as Exchange Rate
Reforms commencing from 1986 with the establishment of the first-tier and second-tier (autonomous) foreign exchange markets. The Government in July 1986 launched the Structural Adjustment Programme (SAP) that had economic and financial deregulation as a major feature. According to Olomola [14], SAP was designed to restructure and diversify the productive base of the economy, achieve fiscal balance, balance of payment equilibrium, intensify growth potential of the private sector and set the economy on the path of steady and balanced growth. One thing that the reform of SAP sorts to achieve was to make agricultural credit properly priced and readily available to farmers, [15, 16]. A major blank of this programme is the restructuring of the fiscal sector and the liberalization of the control and regulation of financial institutions and markets. In 1988 the Bureau de change was established, and in 1992, the devaluation of the official exchange rate took place.

The second was the re-regulation era of 19931998, following the deep financial distress; the third segment was initiated in 1999 with the return of liberalization and the adoption of the universal banking model. The fourth segment commenced in 2004 with banking sector consolidation as a major component and was meant to correct the structural and operational weaknesses that constrained the banks from efficiently playing the catalytic role of financial intermediation. Following from the exercise, the aggregate capital of the consolidated banks rose by 439.4 percent between 2003-2009 while deposit level rose by 241.8 percent. However, this was not reflected in the flow of credit to the agricultural and manufacturing sector, as the growth rate of credit fell during this period, while actual credit did not reflect the proportionate contribution of the sector to the GDP [17].

The present condition of the Nigerian economy is indeed unprecedented in the history of global economic downturn. All macroeconomic indices that spell a nations economic well-being portray a rather pitiable and gloomy outlook for the nation. All these indices point to an economy trapped in vicious cycle of stagnation, declining productivity, rising unemployment, mounting foreign debt, and widening inequality gap at a magnitude without antecedent. Following the collapse of oil prices and the massive shortfall in government revenues and attendant adverse economic and social repercussions, the need for accelerated investments in the Agricultural sector has become more urgent. The provision of credit has increasingly been regarded as an important tool for raising the incomes of farmers, mainly by mobilizing resources to productive uses $[18,19]$. Due to unsatisfactory results of past reforms, it becomes necessary to compare past and presents ones to actually determine the true state of Nigeria's financial sector and how far these reforms have helped the economy to develop. 


\section{Objectives of the study}

The main objective of the study was to examine the impact of financial sector reforms on farmer's access to formal credit. The specific objectives were to:

- Compare the volume of loans accessed by the different agricultural subsectors in the different reforms era.

- Estimate the determinants of farmers access to agricultural loan

- Determine the effect of the different financial sector reforms overtime on farmers' access to loan

\section{THEORETICAL ISSUES}

This study benefits from the credit channel theory and other theoretical literature which suggest that policy may have an effect on credit supply and demand in an economy. Dobrinsky and Markov [20] noted that the recently advanced "credit channel view" implies that monetary policy shocks affect real economic performance through the supply of credit by financial intermediaries due to shifts in the supply schedule of the latter. In turn, they noted, the literature makes a distinction between a "bank lending channel" which pertains to banks only and is related to their dual nature of holders of deposits and generators of loans to firms and a "broad credit Markov channel" which treats the supply of external funds to firms by all financial intermediaries [21] , [20]. The credit channel view is also consistent with the assumption of the existence of market imperfections, in particular, information asymmetries between borrowers and lenders which give rise to the above mentioned monitoring cost premium [22]. One implication of the existence of a credit channel in the monetary transmission mechanism is that it induces a heterogeneous response both of the credit market and of the firms due to which the increase in the cost premium for external finance will not be uniformly distributed across firms. The reason for this heterogeneity is the fact that the existing credit market imperfections are likely to impact in a different manner on various categories of firms in the event of a monetary shock. In particular, the credit channel view is consistent with the empirical finding that the effect of a monetary shock should be more severe for small firms (that are more likely to face information costs) than for large firms [21] or that the negative effect of a monetary contraction on investment is greater for highly leveraged firms (which are more likely to suffer a reduction in their collateralizable net worth due to the monetary shock) than for less leveraged firms [23, 24]. It is worth noting that Nigerian agricultural sector is largely dominated by small-scale farms (or firms) and going by the foregoing empirical findings it would not be out of place to expect monetary policies having some effects on their collaterizable net worth and hence their credit requirements which banks tend to respond to when they supply credit to the agricultural sector. The indicators of financial development which can influence credit supply used in empirical studies can be classified roughly into three broad categories: monetary aggregates, stock market indicators, and structural and institutional indicators. The disaggregated variables for financial variables used in the empirical model for this paper represent the monetary aggregates and stock market indicators. These were applied by Afangideh [25] study which indicated that bank lending to agriculture equation was significantly influenced by domestic credit to the private sector, stock market capitalization, real income and previous period bank lending to agriculture. All had direct and positive effects on bank lending to agriculture except value traded ratio which had a direct but negative effect. Soyibo and Adekanye [26] stressed the special influence of financial reforms on the financial sector and he exemplified the influence by the proxy of exchange rate and interest rate which were acknowledged as the drivers of growth of real sectors of the economy including agriculture.

\section{RESEARCH METHODOLOGY}

The study area is Nigeria. Nigeria has a total geographical area of 923,768 square kilometers, a North-South length of about $1450 \mathrm{~km}$ and West-East breath of about $800 \mathrm{~km}$. Its total boundary is $4047 \mathrm{~km}$, while the coastline is $853 \mathrm{~km}$ and a population estimate of about 167 million [27]. Nigeria is located $4^{0} 16^{\mathrm{I}}$ and $13^{0} 53^{\mathrm{I}}$ north latitudes and $2^{0} 40^{\mathrm{I}}$ and $14^{0} 41^{\mathrm{I}}$ east longitudes. It comprises 36 states and the Federal Capital Territory is located in Abuja.

Nigeria is located in the tropics, which is characterized by high temperatures, high humidity and intense heat. Its rainfall ranges between 2000 to $3000 \mathrm{~mm}$. Nigeria encompasses six (6) major agroecological zones with rainfall diminishing along a South-North gradient. The forest zone borders the coast in the south, and going north-ward way to the Guinea and Sudan Savannah. Nigeria's North-Eastern fringe falls within the Sahel zone [28]. Agriculture is the largest single sector of the economy, providing employment for a significant segment of the work force and constituting the main stay of Nigeria's large rural community which accounts for nearly two-third of the population. The population of the GDP attributed to agriculture hovers between $30-40 \%$. Nigeria is distinguished by the diversity of its ecosystems, an advantage for growing a broad range of crops. Data for the study were obtained from secondary sources. Secondary data were obtained from CBN Statistical bulletin, $\mathrm{CBN}$ annual report, federal budget allocation report, annual reports and used for the study. Data were analyzed using descriptive and inferential statistics. Objective 1was realized using Analysis of variance (ANOVA); 2 and 3 were realized using regression analysis.Multiple regression was used to estimate the determinants of farmers access to agricultural loan.

The empirical models: 1 . To achieve this objective, the volume of agricultural loans accessed by 
the farmers was regressed against average lending and savings rate, saving mobilized by financial institutions, government budget allocation, credit to private sector and direct investment. The models for the study were specified in four functional forms as follows:

linear form: $\mathrm{Y}=\beta_{0}+\beta_{1} X_{1}+\beta_{2} X_{2}+\beta_{3} X_{3}+\beta_{4} X_{4}+\beta_{5} X_{5}+\beta_{6} X_{6}+\mathrm{e}_{t}$ (8)

Semilog form: $\mathrm{Y}=\beta_{0}+\beta_{1} \operatorname{Ln} X_{1}+\beta_{2} \operatorname{Ln} X_{2}+\beta_{3} \operatorname{Ln} X_{3}+\beta_{4} \operatorname{Ln} X_{4}+\beta_{5} \operatorname{Ln} X_{5}+\beta_{6} \operatorname{Ln} X_{6}+\mathrm{e}_{t}$ (9)

Exponential form: $L n \mathrm{Y}=\beta_{0}+\beta_{1} X_{1}+\beta_{2} X_{2}+\beta_{3} X_{3}+\beta_{4} X_{4}+\beta_{5} X_{5}+\beta_{6} X_{6}+\mathrm{e}_{t}$

Double log form: $\operatorname{Ln} \mathrm{Y}=\beta_{0}+\beta_{1} \operatorname{Ln} X_{1}+\beta_{2} \operatorname{Ln} X_{2}+\beta_{3} \operatorname{Ln} X_{3}+\beta_{4} \operatorname{Ln} X_{4}+\beta_{5} \operatorname{Ln} X_{5}+\beta_{6} \operatorname{Ln} X_{6}+\mathrm{e}_{t}$

Where,

$\mathrm{Y}=$ Volume of agricultural loans accessed by farmers (in Millions of Naira)

$\mathrm{X}_{1}=$ Average interest lending rate $(\%)$

$\mathrm{X}_{2}=$ average interest savings rate

$\mathrm{X}_{3}=$ saving mobilized by financial institutions (Millions of Naira)

$\mathrm{X}_{4}=$ Government budget allocation (million Naira)

$\mathrm{X}_{5}=$ Credit to private sector (Millions of Naira)

$\mathrm{X}_{6}=$ Direct investment (in Millions of Naira)

$\beta_{1}-\beta_{6}=$ coefficients of the respective variables.

$\mathrm{e}_{\mathrm{t}}=$ error term

$\mathrm{Ln}=$ Natural logarithm

$\beta_{0}=$ intercept of the model

2. Regression was used to analyze the effect of the different financial sector reform periods on farmers' access to agricultural loan. To achieve this objective, the loan granted to agricultural sector under the different financial sector regime was regressed against the GDP of the different periods.

$\mathrm{Y}=\mathrm{f}\left(\mathrm{X}_{1} \ldots \mathrm{Xn}\right)$

Where,

$\mathrm{Y}=$ Gross Domestic Product of the different financial reform era

$\mathrm{X}_{1} \ldots \mathrm{X}_{\mathrm{n}}=$ loans accessed by farmers under the different financial sector reform era in millions naira

$\mathrm{X}_{1}=$ loan accessed by farmers during the regulatory era (1981-1991)

$\mathrm{X}_{2}=$ loan accessed by farmers during the liberalized regulation era with specialist role (1991-2000)

$\mathrm{X}_{3}=$ loan accessed by farmers during the regulatory era with universal role (2000-2005)

$\mathrm{X}_{4}=$ loan accessed by farmers during the regimented regulation/consolidation era (2005-2009)

$\mathrm{X}_{5}=$ loan accessed by farmers during the regimented regulation/ownership solution era (2009 to date)

\section{Chow test}

The test of structural change of the financial reforms was carried out using the chow test. The test is to ascertain whether financial sector reforms over the years have been stable. Specifically it was used to determine whether the financial reform was the same before and after the regulated era. The test is sought to investigate whether financial reforms have a predictable impact of farmer's access to loan and other variables over the years. The objective was to test for stability of reforms over time between 1981-1990 (regulated) and 1991-2016(deregulated period). The chow test formula is expressed thus:

$F^{*}=\left(\frac{\left\{\sum e_{p}^{2}-\left(\sum e_{1}^{2}+\sum e_{2}^{2}\right) / k\right\}}{\left(\sum e_{1}^{2}+\sum e_{2}^{2}\right) /\left(n_{1}+n_{2}-2 k\right)}\right)$

where:

$F^{*}=$ observed $\mathrm{F}$ ratio

$\sum e_{p}^{2}=$ Pooled unexplained variations of two periods: 1981-1990(regulated) and 1991-2016(deregulated)

$\sum e_{1}^{2}=$ unexplained variations of finacial reforms in regulated period(1981-1990)

$\sum e_{2}^{2}=$ unexplained variations of finacial reforms in deregulated period(1991-2016)

$n_{1}=$ number of observations in the regulated period(1981-1990)

$n_{2}=$ number of observations in the deregulated period(1991-2016)

$\mathrm{k}=$ total number of coefficients including the intercept

$n_{1}+n_{2}-2 k=$ Degrees of freedom 


\section{RESULTS AND DISCUSSION \\ The Financial Sector Reforms \\ The Free Banking Era (1892-1951)}

The Free Banking Era (1892-1951) was adopted due to absence of control over any bank. The Nigerian government during the colonial period adopted the exploitative strategy for agricultural development. In the 1950s, the traditional economists observed agricultural sector as a residual, subsistence sector made up of peasant farmers. According to Myint 1958 as cited in Akpaeti [2], in his vent-for-surplus theory particularly categorized a developing economy as consisting of a "modern sector "that is largely nonagricultural and a "subsistence sector" that is agricultural. The subsistence sector that is perceived to be unproductive but full of under-utilized resources is expected to feed the modern sectors. As such, the subsistence sector was expected to be taxed to finance the modern sector. This essentially was the basis of the agricultural strategy in 1950s in Nigeria with levies on export crops providing revenue for government to develop the modern sector [29]. The government established institutions such as the agricultural marketing board system to boast revenue generation efforts through taxing of peasant farmers that produce export crops such as cocoa, groundnut, palm produce, cotton [30].

\section{The Regulatory Era (1952-1991)}

In this period three exchange rate systems were adopted from 1960 to 1972 . These are the fixed rate system which was adopted from 1960 to 1972, the managed floating system from 1973 to 1978, and the pegged system, that is pegged to a currency basket was adopted from 1979 to 1985 . Out of these financial sector reforms in the economy, the creation of Nigerian Agricultural and Cooperative Bank in 1973, World Bank Agricultural Development Projects in 1975, the launching of Rural Banking in 1977, the Agricultural Credit Guarantee Scheme Fund (ACGSF) launched in 1977 , the mandatory sectoral allocation to agriculture and the deregulation of banking in 1986 which provided the impetus for the Structural Adjustment Programme affected agricultural development directly.

\section{The Liberalized Regulation Era with Specialist Roles (1991- 2000)}

The Financial liberalization that took place in developing countries in the late 1990s was part of a general move toward giving markets a greater role in development; a desire for cheaper and better finance; and the growing difficulties of using capital controls in a world of increased trade, travel, migration and communications. It differed in timing speed and content across countries, but it always involved freeing interest rates and allocations, privatizing state banks and pension payments, developing financial markets, and encouraging competition between banks (and sometimes non-banks). Financial liberalization is viewed as a process of moving towards market determined interest rate as well as market determined prices on all classes of financial products. It also involves banking systems characterized by symmetric entry and exit conditions of all participants, increasing internationalization or the opening up of the domestic market to international competition and limited barriers to the introduction of new financial products" [31]. This was explained in simple words by Tseng and Coker [32] saying "that financial liberalization involves changes in the financial structure by going further to list the changes as liberalization of interest rate, reduction or abolition of credit controls, removal of limits on scope of banking activities, banking system reforms, reduction or abolition of foreign exchange controls and free entry of foreign institution to domestic financial markets". Financial liberalization consists of the deregulation of the foreign sector capital account, the domestic financial sector and the stock market sector viewed separately from the domestic financial sector [33]. This era witnessed the following financial reforms: 1991 Embargo on bank licensing, strengthening of bank regulation and supervision and partial privatization of banks, 1992-Privatization of banks commenced, 1993Restructuring of distressed banks, 1994 -Liquidation of banks, 1995 -Liberalization of capital flows,1996 Liberalization of the capital, 1997 - Capital market reforms (partial in 1993), 1999 -Re-entry of foreign fully owned banks, 2000 -Institutionalization of foreign currency deposits $[8,30]$.

\section{The Liberalized Regulation Era with Universal Roles (2000 -2005)}

The era of liberalized regulation with universal roles started in $2000-2005$ which witnessed the combination of commercial banking and investment banking. It is a supermarket for both wholesaler and retailer financial services as it offers a wide range of financial services Sanders and Walter see it as the conduct of a range of financial services comprising deposit taking and lending, trading of financial instruments and foreign exchange (and other derivatives) underwriting of new debt and equity issues, brokerage, investment and insurance. Alegieuno [34] corroborates this but expanded its scope. Universal banking was seen as the business of receiving deposits on current, savings or other accounts; paying or collecting cheques drawn or paid in by customers; provision of finance, consultancy and advisory services relating to corporate and investment matters: making or managing investment on behalf of any person; and the provision of insurance marketing services and capital market business or such other services as the Governor of the Central Bank of Nigeria (CBN) may regulate or designate as banking business. Under this concept, banks are free to choose which activity or activities to undertake (money or capital market activities or insurance marketing services or a combination thereof) and are expected to comply with the guidelines 
specified for such activity or activities. The universal banking system allows banks to operate in all sectors without differentiation as merchants, commercial or mortgage banks. In this respect, Jimoh [35] defines universal banking as a system where banks are allowed to provide a variety of services to their customers. Through the system, commercial banks are encouraged to operate and extend their primary mandated financial functions and incorporating along other operations such as Mutual Funds, Merchant Banking, factoring, insurance, credit cards, retail loans, housing financial, trusteeship and Allied services, stock broking. Onu (2013) stated that universal banking was designed to ensure a diversified strong and reliable banking that would stimulate the economic growth of the nation. The adoption and implementation of universal banking system and other reforms that accompany it would herald rapid and sustainable development and economic growth in the country.

\section{The Regimented Regulation/Consolidation (2005 - 2009)}

This reform which began in 2004 was necessitated by the need to strengthen the banks. The policy thrust at inception was to grow the banks and position them to play pivotal roles in driving development across the sectors of the economy. As a result banks were consolidated through mergers and acquisitions raising the capital base from $\mathrm{N} 2$ billion to a minimum of $\mathrm{N} 25$ billion, which reduced the number of banks from 89 to 25 in 2005, and later to 24. Beyond the recapitalization of banks, the regulatory reforms also focused on: Risk and rule based regulatory framework; Zero tolerance in regulatory framework in data/information rendition/reporting and infractions; Strict enforcement of corporate governance principles in banking; Revision and updating of relevant-laws for effective corporate governance and ensuring greater transparency and accountability in the implementation of banking of laws and regulations, as well as; The introduction of a flexible interest rate-based framework that made the monetary policy rates the operating target. The new framework has enabled the CBN to be proactive in countering inflationary pressures. The corridor regime has helped to check wide fluctuations in the interbank rates and also engendered orderly development of the money market and payment system reforms; amongst others (Nigeria's banking reforms, 2014).

\section{The Regimented Regulation/Ownership Solution (2009 -Date)}

This era witnessed the following financial reforms: 2010-Abolishment of Universal Banking; 2010-Creation of Asset Management Company (AMCON) 2010-Comprehensive review of provisional guideline for margin loans. 2010-Institutionalizing corporate governance for regulators and operators. 2010-Creation of risk department for micro guideline [8].

One of the financial sector reforms from the period 2009 to date that affected agriculture positively is the creation of the risk department for micro guideline. Credit risk is the risk of loss caused by the failure of a counter party to meet its obligations. "In other words, it refers to the delinquency and default by borrowers, i.e failure to make payment as at when due or non-payment by those owning the firm. Credit risk and default management has become a complex subject and its mitigation to acceptable levels is a major concern for all financial institutions [36].

Table-1: Total commercial bank loan to agricultural sector under the different financial sector regime

\begin{tabular}{|l|c|l|}
\hline \multicolumn{1}{|c|}{ Era } & Year & Volume of loan(billion) \\
\hline Regulatory era & $1952-1991$ & 24.7086 \\
\hline Liberalized regulation era with specialist role & $1991-2000$ & 245.94 \\
\hline Liberalized regulation era with specialized roles & $2000-2005$ & 335.13 \\
\hline Regimented regulation/consolidation & $2005-2009$ & 489.59 \\
\hline Regimented regulation/ownership solution & 2009 to date & 2543.853 \\
\hline
\end{tabular}

Source: CBN bulletin, 2016.

\section{Compare the volume of loan accessed by the different agricultural subsectors during the financial reforms period}

Table 2, presents the result of the mean volume of loan accessed by the different agricultural subsector during the regulated and deregulated periods. The result showed that in terms of nominal value, that the deregulated period had the highest mean value of loan (3474.689) accessed across the three subsectors as compared to that of the regulated period. However, in terms of real values (i.e accounting for inflationary pressure), it was revealed that the regulated period had the highest mean value of loan (53.506) as compared to the deregulated period. 
Eyo Emmanuel O \& Agenson M. Eleojo; Saudi J Bus Manag Stud, Sep 2019; 4(9): 712-722

Table-2: Mean volume of loan accessed by the different agricultural subsector during the regulated and deregulated periods

\begin{tabular}{|c|c|c|}
\hline & $\begin{array}{c}\text { Mean volume of loan } \\
\text { (Nominal values) }\end{array}$ & $\begin{array}{c}\text { Deregulated } \\
(1991-2016)\end{array}$ \\
\hline Agric subsector & $\begin{array}{c}\text { Regulated } \\
(1981-1990)\end{array}$ & 2638.7288 \\
\hline Crop & 38.5603 & 649.0302 \\
\hline Livestock & 18.1264 & 186.9295 \\
\hline Fisheries & 2.2307 & $\mathbf{3 4 7 4 . 6 8 9}$ \\
\hline Total & $\mathbf{5 8 . 9 1 7}$ & \\
\hline & $\begin{array}{c}\text { Mean volume of loan } \\
\text { (Real values) }\end{array}$ & $\begin{array}{c}\text { Deregulated } \\
(1991-2016)\end{array}$ \\
\hline Agric subsector & $\begin{array}{c}\text { Regulated } \\
(1981-1990)\end{array}$ & 30.697 \\
\hline Crop & 28.257 & 6.467 \\
\hline Livestock & 23.500 & 1.856 \\
\hline Fisheries & 1.749 & $\mathbf{3 9 . 0 2 0}$ \\
\hline Total & $\mathbf{5 3 . 5 0 6}$ & \\
\hline
\end{tabular}

Source: Computed from CBN Bulletin, 2016.

Table-3: Descriptive estimates comparing the volume of loan accessed by the different agricultural subsectors

\begin{tabular}{|l|r|r|r|r|r|}
\hline Volume of Loan accessed & Count & \multicolumn{1}{c|}{ Sum } & \multicolumn{1}{c|}{ Mean } & Variance & \multicolumn{1}{c|}{ SS } \\
\hline Crop sector & 36 & 68992.55 & 1916.46 & 6378235 & $2.23 \mathrm{E}+08$ \\
\hline Livestock sector & 36 & 17056.05 & 473.7792 & 525873 & 18405553 \\
\hline Fishery sector & 36 & 4882.473 & 135.6242 & 44517.81 & 1558123 \\
\hline
\end{tabular}

The difference in the volume of loan accessed by the different agricultural subsector during the regulated and deregulated financial reforms period is presented in Table 3. The result showed that there was a difference in volume of loan accessed by the subsector. The volume of loan accessed by crop, livestock and fishery subsector differed in mean. The difference in the annual mean volume of loan accessed by crop and livestock subsector during the regulated reform period was 20.4339 and was statistically significant at $10 \%$ level of significance, while that of the crop and livestock, livestock and fisheries subsector during the regulated reform period were 36.3296 and 15.8957 and were statistically significant at $1 \%$ level of significance respectively. Furthermore, the difference in the annual mean volume of loan accessed by crop and livestock subsector during the deregulated reform period was 1989.75 and was statistically significant at $1 \%$ level of significance, while that of the crop and livestock, livestock and fisheries subsector during the deregulated reform period were 2451.851 and 462.101 and were statistically significant at $1 \%$ level of significance respectively. However, the null hypothesis of no significant difference between the loans accessed by the agric subsector was rejected. This was shown in the student t-test estimate in Table 3 . The result revealed that the student $\mathrm{t}_{\mathrm{tab}}$ was greater than the $\mathrm{t}_{\mathrm{cal}}$ at $10 \%$ and $1 \%$ level of significance for both periods. Thus, it is concluded that there is a significant difference between the loans accessed by the agricultural subsector in the different reform periods. Also, the \% contribution of the total loan to the total output of the various crops was $75.87 \%, 18.76 \%$ and $5.37 \%$ respectively. This result revealed that the loan accessed by the crop sector contributed more to the total output during the period of the study. This result is supported by the values in Table1 which showed that the crop sectored recorded the highest volume of loan accessed.

Table-4: Student t-test estimates comparing the volume of loan accessed by the different agricultural subsectors

\begin{tabular}{|c|c|c|c|c|}
\hline Subsector & Mean annual loan & Differences & $\mathrm{T}_{\mathrm{cal}}$ & $\mathrm{T}_{\mathrm{tab}}$ \\
\hline & & Regulated era(1981-1990) & & \\
\hline Crop & $38.5603(36.92)$ & 20.4339 & $1.7092 *$ & 1.40 \\
\hline Livestock & $18.1264(8.14)$ & & & \\
\hline $\begin{array}{l}\text { Crop } \\
\text { fisheries }\end{array}$ & $\begin{array}{l}38.5603(36.92) \\
2.2307(1.93)\end{array}$ & 36.3296 & $3.1075 * * *$ & 2.31 \\
\hline \multirow{3}{*}{$\begin{array}{l}\text { Livestock } \\
\text { fisheries }\end{array}$} & $18.1264(8.14)$ & 15.8957 & $6.0091 * * *$ & 2.31 \\
\hline & & & & \\
\hline & & Deregulated era(1991-2016) & & \\
\hline Crop & $2638.78(2641.19)$ & 1989.75 & $3.6809 * * *$ & 2.06 \\
\hline Livestock & 649.03(788.168) & & & \\
\hline $\begin{array}{l}\text { Crop } \\
\text { fisheries }\end{array}$ & $\begin{array}{l}2638.78(2641.19) \\
186.929(229.06)\end{array}$ & 2451.851 & $4.7159 * * *$ & 2.06 \\
\hline Livestock & 649.03(788.168) & 462.101 & $2.8708 * * *$ & 2.06 \\
\hline fisheries & $186.929(229.06)$ & & & \\
\hline
\end{tabular}

Source: Computed from CBN data, 2016. 


\section{Determinants of farmer's access to agricultural loan}

The determinants of farmers access to agricultural loan is presented in Table 5 and shown in equation 1. The double log model was chosen as the lead equation. The choice of the lead equation was based on the statistical significance of the coefficients, the correct sign and the value of $\mathrm{R}^{2}$. The adjusted $\mathrm{R}^{2}$ value implies that $93 \%$ of the variation in agricultural loan is explained by the explanatory variables included in the model, while the significant $\mathrm{f}$ statistic implies that the combine effect of all the explanatory variables on agricultural loan was significant.

The result showed that savings mobilized by financial institution(X3), government budget allocation to agriculture $(\mathrm{X} 4)$ and credit to private sector (X5) were the significant determinants of farmer's access to agricultural loan. Specifically, the coefficient of savings mobilized by financial institution (X3) was positive (2.2877) and statistically significant at 5\% level of significance. This implies that a unit increase in savings mobilized by financial institution will increase farmer's access to agricultural loan by 2.2877. The result corroborate with that of Akudugu [41]. In his study savings was positive and significantly related with credit demand.

Similarly, government budget allocation to agriculture had a positive $(0.4255)$ and significant effect on farmer's access to agricultural loan. This implies that a unit increase in government budget allocated to agriculture will increase farmer's access to agricultural loan by 0.4255 . The coefficient of credit to private sector (-2.0422) was also negative and statistically significant at $1 \%$ level, denoting farmer's access to agricultural loan declines with an increase to credit to the agric private sector. Both average interest lending rate and average interest savings rate had a negative but not significant effect on farmer's access to agricultural loan. The coefficient of average interest lending rate and average interest savings rate were -0.1658 and 0.2469 respectively. This implied that farmer's access to agricultural loan declined with an increase in interest lending rate and interest savings rate. Ololade and Olagunju [37] concluded that farmers' access to credit is positively affected by availability of guarantors and a unit increase in interest rate would lead to the probability of not having access to credit. Akudugu [38] also had a negative but not significant impact between interest lending rate and credit demand by farmers.

The coefficient of direct investment into Nigeria's economy was positive (0.2806) but not statistically significant. This implied that farmer's access to agricultural loan would increase as direct investments to the economy increases.

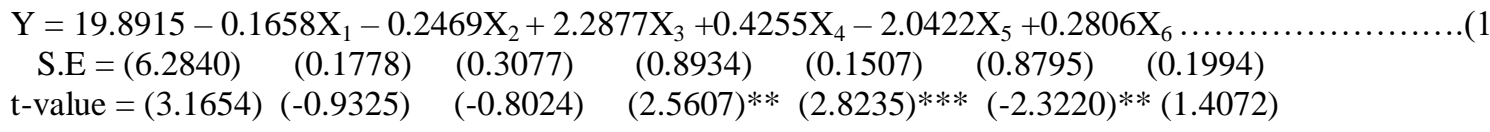

Table-5: Determinants of farmer's access to agricultural loan

\begin{tabular}{|c|c|c|c|c|}
\hline Variable & Double $\log (+)$ & Linear & Exponential & Semilog \\
\hline Constant & $\begin{array}{c}19.8915^{* * * *} \\
(6.2840)\end{array}$ & $\begin{array}{c}655462 \\
(1.17 \mathrm{e}+06)\end{array}$ & $\begin{array}{c}11.6387 * * * \\
(0.5807)\end{array}$ & $\begin{array}{l}4.38 \mathrm{e}+07 * \\
(2.51 \mathrm{e}+07)\end{array}$ \\
\hline Average interest lending rate & $\begin{array}{c}-0.1658 \\
(0.1778)\end{array}$ & $\begin{array}{l}-53560.6 \\
(125283)\end{array}$ & $\begin{array}{c}0.1356^{* *} \\
(0.0618)\end{array}$ & $\begin{array}{l}-603478 \\
(711815)\end{array}$ \\
\hline Average interests Savings rate & $\begin{array}{l}-0.2469 \\
(0.3077)\end{array}$ & $\begin{array}{c}-34782 \\
(84109.9)\end{array}$ & $\begin{array}{c}-0.0698 \\
(0.04150\end{array}$ & $\begin{array}{c}-1.21 \mathrm{e}+06 \\
(1.23 \mathrm{e}+06)\end{array}$ \\
\hline Saving mobilized by financial institutions & $\begin{array}{c}2.2877 * * \\
(0.8934)\end{array}$ & $\begin{array}{c}3315.79 * * * \\
(824.44)\end{array}$ & $\begin{array}{c}0.0010 \\
(0.0004)\end{array}$ & $\begin{array}{c}7.789 \mathrm{e}+06^{* *} \\
(3.57 \mathrm{e}+06)\end{array}$ \\
\hline Government budget allocation & $\begin{array}{c}0.4255^{* * * *} \\
(0.1507)\end{array}$ & $\begin{array}{c}34.039 * * * \\
(12.133)\end{array}$ & $\begin{array}{c}2.56 \mathrm{e}-05^{* *} \\
(5.98 \mathrm{e}-06) \\
\end{array}$ & $\begin{array}{l}-262994 \\
(603301) \\
\end{array}$ \\
\hline Credit to private sector & $\begin{array}{c}-2.0422 * * \\
(0.8795)\end{array}$ & $\begin{array}{c}-1.8487 * * * \\
(0.6220)\end{array}$ & $\begin{array}{c}-4.57 \mathrm{e}-07 * * * \\
(3.07 \mathrm{e}-07)\end{array}$ & $\begin{array}{c}-6.11 \mathrm{e}+06^{*} \\
(3.52 \mathrm{e}+06)\end{array}$ \\
\hline Direct investment & $\begin{array}{c}0.2806 \\
(0.1994)\end{array}$ & $\begin{array}{c}0.2532 \\
(0.4186) 0.83\end{array}$ & $\begin{array}{c}-1.06 \mathrm{e}-07 \\
(2.08-07)\end{array}$ & $\begin{array}{l}-46146.1 \\
(797983)\end{array}$ \\
\hline \multicolumn{5}{|l|}{ Diagnostic } \\
\hline R-squared & 0.9397 & 0.83 & 0.85 & 0.73 \\
\hline Adjusted R-squared & 0.9273 & 0.80 & 0.82 & 0.68 \\
\hline F-stat & 75.3649 & 24.2475 & 28.1615 & 13.2728 \\
\hline
\end{tabular}

Note; $* * *$ significant at $1 \%, * *$ significant at $5 \%, *$ significant at $10 \%$. Figures in parenthesis are standard errors. + ; lead equation 
Determine the effect of the different financial sector regime on farmers' access to loan.

The result showing the effect of the different financial sector regime on farmers' access to loan is presented in Table 5. The result revealed that the period of the regulatory era (1981-1991), liberalized regulation era with specialist role (1991-2000) and the regimented regulation/ownership solution (2009-2016) all had a positive and significant effect on farmers' access to loan. The coefficient of the variables was positive and statistically significant at $1 \%$ level of significance respectively. This result is in line with study by Omankhanlen [8]. He obtained a positive and significant relationship between banking reforms and real sector financing measured by loans and advances. The finding also agrees with the theories advocated by pro financial sector reforms and World Bank [39]. Onoja et al. [40] obtained a significant difference in the levels of loans granted by the sector of the economy before and after the financial sector reforms.

$$
\begin{aligned}
\mathrm{Y} & =0.0244 \mathrm{X} 1+0.0439 \mathrm{X} 2+0.0808 \mathrm{X} 3+0.0339 \mathrm{X} 4+0.0237 \mathrm{X} 4 \ldots \\
\mathrm{t}-\text { value } & =(24.400)^{* * *}(10.707)^{* * *}(0.099) \quad(18.833)^{* * *}(11.286) * * *
\end{aligned}
$$

Table-6: Effect of the different financial sector regime on farmers' access to loan

\begin{tabular}{|l|c|c|c|}
\hline Reform era & Year & Coefficient & $\mathbf{R}^{\mathbf{2}}$ \\
\hline Regulatory era & $1981-1991$ & $\begin{array}{c}0.0244 \\
(0.0010)^{* * *}\end{array}$ & 0.98 \\
\hline Liberalized regulation era with specialist role & $1991-2000$ & $\begin{array}{c}0.0439 \\
(0.0041)^{* * *}\end{array}$ & 0.93 \\
\hline Liberalized regulation era with specialized roles & $2000-2005$ & $\begin{array}{c}0.0808 \\
(0.8135)\end{array}$ & 0.19 \\
\hline Regimented regulation/consolidation & $2005-2009$ & $\begin{array}{c}0.0339 \\
(0.0018)\end{array}$ & 0.54 \\
\hline Regimented regulation/ownership solution & 2009 to date & $\begin{array}{c}0.0237 \\
(0.0021)^{* * *}\end{array}$ & 0.95 \\
\hline
\end{tabular}
Source: Computed from CBN Bulletin, 2016.Note; *** significant at 1\%, ** significant at 5\%

\section{Test of stability of financial reforms in Nigeria.}

Table 7. shows the summary result of the test of structural change of the different financial reforms in Nigeria. The calculated F is 0.079 and it is clearly lower than the tabulated value of 3.94 at the $5 \%$ level of significance. Based on this result, we do not reject the null hypothesis. Thus we conclude that the financial reforms for Nigeria have not been changing over time, which implies that it has been stable over time. The implied stability therefore suggested that financial reforms have been having predictable effect on price deflator for agricultural commodities, interest rate, stock market capitalization, nominal exchange rate, value of agricultural output as share to total real GDP and volume of credit advanced to the core private sector.

Table-7: Summary result of the test of structural change of the financial reforms in Nigeria

\begin{tabular}{|l|l|l|l|}
\hline Period & $\begin{array}{l}\text { Pooled sample } \\
\text { 1981-2016 }\end{array}$ & $\begin{array}{l}\text { Regulated period } \\
\mathbf{1 9 8 1 - 1 9 9 0}\end{array}$ & $\begin{array}{l}\text { Deregulated-period } \\
\mathbf{1 9 9 1 - 2 0 1 6}\end{array}$ \\
\hline & $8.54 \mathrm{e}+15$ & $7.31 \mathrm{e}+08$ & $8.33 \mathrm{e}+13$ \\
\hline $\mathrm{N}$ & 36 & 10 & 26 \\
\hline Fcal & 0.079 & & \\
\hline Fcrit $(5 \%)$ & 3.94 & & \\
\hline
\end{tabular}

Source: Computed from CBN data, 2016.

\section{CONCLUSION}

The study examines the impact of financial sector reforms on farmer's access to loan in Nigeria spanning from 1981 to 2016 . The specific objectives were to; compare the volume of loan accessed by the different agricultural subsectors in the different financial reform periods, estimate the determinants of farmers access to agricultural loan, determine the effect of the different financial sector reforms overtime on farmers' access to loan. Results obtained shows that there were a significant differences in volume of loan accessed by the subsector. The result also showed that amount of loan had a significant impact on crop and livestock output. The estimated impact of loan on crop (11.2423) and livestock (2.3424) and fisheries (2.6629) output were positive and statistically significant at $1 \%$ level of significance. Its impact were positive for both $\operatorname{crop}(17288.5)$ and fisheries(356.299) output at $1 \%$ level of significance, while that of livestock subsector was negative(-880.593) and significant at 5\%. However, all variables had a high $\mathrm{R}^{2}$ value of $0.87,0.72$ and 0.78 respectively. Further result showed that savings mobilized by financial institution, government budget allocation to agriculture and credit to private sector were the significant determinants of farmer's access to agricultural loan. The study revealed that financial sector regime era had a significant effect on farmers' 
access to loan. The regulated era, liberalized regulation era with specialist role and regimented regulation/ownership solution had a positive and significant effect on farmers' access to loan.

\section{REFERENCES}

1. Balogun, E. D. (2007). A review of Soludo's perspective of banking sector reforms in Nigeria.

2. Akpaeti, A. J. (2015). Impact of Financial Sector Reforms on Agrcultural Growth in Nigeria: A Vector Autoregressive (VAR) Approach. American Journal of Experimental Agriculture, 7(1), 17-35.

3. Longman, R. W. (2000). Iterative learning control and repetitive control for engineering practice. International journal of control, 73(10), 930-954.

4. Bonney, M., \& Jaber, M. Y. (2011). Environmentally responsible inventory models: Non-classical models for a non-classical era. International Journal of Production Economics, 133(1), 43-53.

5. Opler, T., Pinkowitz, L., Stulz, R., \& Williamson, R. (1999). The determinants and implications of corporate cash holdings. Journal of financial economics, 52(1), 3-46.

6. Abiad, A., \& Mody, A. (2005). Financial reform: What shakes it? What shapes it?. American Economic Review, 95(1), 66-88.

7. Ojo, A. T. (2010). The Nigerian maladapted financial system: Reforming tasks and development dilemma. Lagos: The CIBN Press Limited.

8. Omankhanlen, A. E. (2012). The financial sector reforms and their effect on the Nigerian economy. Economy

Cognition, 15(2), 45-57.

Transdisciplinarity

9. Okorie, M. C., \& Agu, D. O. (2015). Does banking sector reform buy efficiency of banking sector operations? Evidence from recent Nigeria's banking sector reforms. Asian Economic and Financial Review, 5(2), 264-278.

10. Eichengreen, B., Gullapalli, R., \& Panizza, U. (2011). Capital account liberalization, financial development and industry growth: A synthetic view. Journal of International Money and Finance, 30(6), 1090-1106.

11. Campbell, O., \& Asaleye, J. A. (2016). Financial Sector Reforms and Output Growth in Manufacturing: Evidence from Nigeria. American International Journal of Contemporary Research, 6(3).

12. Emanghe, E. E., \& Udedeh, C. C. (2018). Principals' Personal Variables and Management of Statutory Records in Secondary Schools in Akwa Ibom State of Nigeria. International Journal of Current Innovations in Advanced Research, 1(3), 39-45.

13. Ogujiuba, K. \&Obiechina, M.E.(2011).Financial Sector Reforms in Nigeria: Issues and Challenges.International Journal of Business and Management, 6(6), 222-231.
14. Olomola, A. S. (1994). Financial liberalization and economic growth under the structural adjustment in Nigeria, Africa Journal of Economic Policy, 1(1), 5-7.

15. Eyo, Emmanuel O.(2008); Macroeconomic Environment and Agricultural Sector Growth in Nigeria. World Journal of Agricultural Sciences 4(6):781 - 786. Pakistan.

16. Eyo, E. O. and I. A. Asuquo, (2011): Determinants of Allocation of Credit Reserve to Loans among Crop Farmers in Cross River State, Nigeria. The Indian Journal of Economics. Vol. XIC, Part IV Issue No 363,,Pp691-698.

17. Anyanwu, C.A. (2010). An overview of current banking sector reforms and the real sector of the Nigerian Economy, Central Bank of Nigeria. CBN Economic and Financial Review, 48(4), 31-57.

18. Atieno, R. (2001). Formal and informal institutions' lending policies and access to credit by small-scale enterprises in Kenya: An empirical assessment.

19. Eyo, E. O. (2002). The Model For Linking Savings And Credit Groups With Banks In Akwa Ibom State, Nigeria. Global Journal of Pure and Applied Sciences, 8(2), 245-252.

20. Dobrinsky, R., \& Markov, N. (2003). Policy regime change and corporate credit in bulgaria: asymmetric supply and demand responses.

21. Oliner, S. D., \& Rudebusch, G. D. (1996). Is there a broad credit channel for monetary policy?. Economic Review-Federal Reserve Bank of San Francisco, 3-13.

22. Glenn, H. R. (1995). Is there a "Credit Channel" for Monetary Policy. Federal Reserve Bank of St. Louis.

23. Rondi, L., Sack, B., Schiantarelli, F., \& Sembenelli, A. (1998). FIRMS'FINANCIAL AND REAL RESPONSES TO MONETARY TIGHTENING: EVIDENCE FOR LARGE AND SMALL ITALIAN COMPANIES. Giornale degli Economisti e Annali di Economia, 35-64.

24. Hu, L. T., \& Bentler, P. M. (1999). Cutoff criteria for fit indexes in covariance structure analysis: Conventional criteria versus new alternatives. Structural equation modeling: a multidisciplinary journal, 6(1), 1-55.

25. Afangideh, U. J. (2010). Financial development and agricultural investment in Nigeria: Historical simulation approach. Journal of Economic and Monetary Integration, 9(1), 74-97.

26. Soyibo, A., \& Adekanye, F. (1992). Financial sector regulation, deregulation and savings mobilization in Nigeria. African Economic Research Consortium (AERC) Research Paper, 11.

27. National Population Commission. (2006). National population census. Abuja, Nigeria: National Population Commission, 422 ..

28. Adeyeye, V. A. (2012). Strategies for enhancing consumption of locally produced rice in 
Nigeria. Nigerian Institute of Social and Economic Research (NISER), Ibadan, Nigeria.

29. Adeyeye, V. A. (2012). Strategies for enhancing consumption of locally produced rice in Nigeria. Nigerian Institute of Social and Economic Research (NISER), Ibadan, Nigeria.

30. Etim, N.A., \&Benson,D.N.(2015). Financial sector reforms and agricultural development in Nigeria. International Journal of Investment Management and Financial Innovations, 1(1), 16-26.

31. Ikhide, S. (1998). Financial sector reforms and monetary policy in Nigeria IDS Working Paper, 68, London. International Economic Review, 35, 535551.

32. Tseng, W., \& Corker, R. (1991). Financial liberalization, monetary policy in Asian countries. International Monetary Fund Occasional Paper, 84, 11-22.

33. Kamisky, O., \&Schmunkler, S. L. (2003). Shortrun pain, long-run gain: The effects of financial liberalization, international monetary fund working paper, WP/03/34, Washington, DC-IMF.

34. Alegieuno, G. A. (2000). Arguments for and Against the Adoption of Universal Banking in Nigeria. CBN Bullion, 24(4), 11-19.

35. Jimoh, F. O., Adedapo, A. A., \& Afolayan, A. J. (2010). Comparison of the nutritional value and biological activities of the acetone, methanol and water extracts of the leaves of Solanum nigrum and Leonotis leonorus. Food and Chemical Toxicology, 48(3), 964-971.
36. Ejike, R. D., Ohiarianya, D. O., \&Lemchi, J. I. (2012). Agricultural credit, risk and default management by banks in Imo State. Nigeria Greener Journal of Agricultural Sciences, 3(2), 137-144.

37. Ololade, R. A., \& Olagunju, F. I. (2013). Determinants of access to credit among rural farmers in Oyo State, Nigeria. Global Journal of Science Frontier Research Agriculture and Veterinary Sciences, 13(2), 16-22.

38. Akudugu, M.A. (2012). Estimation of the Determinants of Credit Demand by Farmers and Supply by Rural Banks in Ghana's Upper East Region. Asian Journal of Agriculture and Rural Development, 2(2), 189-200.

39. World Bank (1996). Nigeria Poverty in the Midst of Plenty. The Challenge of Growth with Inclusion. A World Bank Poverty Assessment, May.

40. Blessing, A., \& Onoja, E. E. (2015). The role of financial statements on investment decision making: a case of united bank for Africa PLC (2004-2013). European Journal of Business, Economics and Accountancy, 3(2), 12-37.

41. Akpaeti, A.J. (2012). Impact of financial sector reforms on agricultural investments and growth in Nigeria. Unpublished Ph.D Dissertation, Department of Agricultural Economics, Michael Okpara University of Agriculture, Umudike, Nigeria, 1-197. 